\title{
Growth Inhibitory Impact of Peganum harmala L. on Two Breast Cancer Cell Lines
}

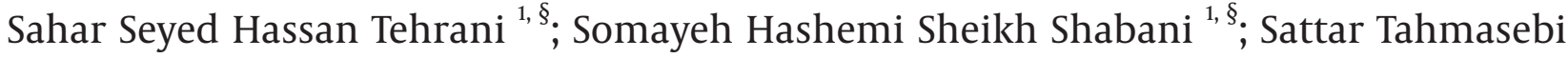 \\ Enferadi ${ }^{1,} ;$ Zohreh Rabiei $^{1}$ \\ ${ }^{1}$ National Institute of Genetic Engineering and Biotechnology, Tehran, IR Iran \\ ${ }^{*}$ Corresponding author: Sattar Tahmasebi Enferadi, National Institute of Genetic Engineering and Biotechnology, Tehran freeway 15 Km, Pajouhesh BLV, Zip Code: 1417863171, P. O. Box: \\ 14925/16, Tehran, IR Iran. Tel: +98-2144580429, Fax:+98-2144580399, E-mail: tahmasebi@nigeb.ac.ir

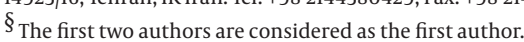

Received: May 24, 2013; Revised: October 10, 2013; Accepted: March 3, 2014

Background: ß-carbolines, harmaline and harmine, are major alkaloids present in the seeds of Peganum harmala L. These alkaloids are known as herbal active principals with potential use in pharmaceutical and medicine.

Objectives: To assess the growth inhibitory effect of phyto-alkaloids, harmaline and harmine, on cancer cell lines.

Materials and Methods: $P$. harmala L.'s alkaloids were extracted by acidic/basic extraction method and identified by two methods, Fourier Transform Infra-Red Spectroscopy (FTIR) and High Performance Liquid Chromatography(HPLC). Two breast cancer cell lines, MDA-MB-231 and Mcf-7, were subjected to different concentrations $\left(1-100 \mu \mathrm{g} \cdot \mathrm{mL}^{-1}\right)$ of the P. harmala extract at different time courses $(24,48$, and 72 hours). Methylthiazol Tetrazolium (MTT) test, half maximal inhibitory concentration ( $\left.\mathrm{IC}_{50}\right)$ and morphological changes through optical microscopy were evaluated.

Results: In both studied cell lines, the $P$. harmala extract decreased cell viability in longer time exposure in a dose dependent manner. The more concentrated extract led to higher motility of MDA-MB-231 at 24 hours. Although, Mcf-7 cell line required longer exposure time to reach the same motility. It was observed that $30 \mu \mathrm{g} \cdot \mathrm{mL}^{-1}$ is the minimum lethal dose that kills approximately $50 \%$ of cells at 24 hours for MDA-MB-231 cell line $\left(\mathrm{IC}_{50}\right)$. IC $\mathrm{C}_{50}$ for Mcf-7 was calculated $40 \mu \mathrm{g} \cdot \mathrm{mL}^{-1}$ and $25 \mu \mathrm{g} \cdot \mathrm{mL}^{-1} 48$ and 72 hours after being exposed against harmala's extract, respectively. The morphological observation confirmed the apoptosis nature of $P$. harmala on cells as their membrane kept intact and no membrane permeabilization was observed.

Conclusions: The results revealed that the P. harmala extracts significantly decreased the growth rate and cell survival of cancer cell lines. The extract induced cell death regarding natural cell growth rate. MDA-MB-231 cell line naturally has a higher growth rate than Mcf-7 cell line, thus higher growth inhibition of MDA-MB-231 cell line by the P. harmala extract was confirmed.

Keywords: Cell viability; FT-IR; HPLC; Harmaline; Harmine; MTT test

\section{Background}

Herbal medicine has been used for centuries to treat many different health conditions and nowadays they are receiving increased attention, as they are cheap, locally available and have fewer side effects. A study estimated that $60-80 \%$ of antibacterial and anticancer drugs were derived from natural products (1).

Peganum harmala L. (a genera from family of Nitrariaceae), also known as Syrian Rue, is a medical herb distributed over semi arid areas of North-West India, North-Africa and Central Asia. This plant is known as "Espand" in Iran, "Harmel" in North Africa and "African Rue", "Mexican Rue" or "Turkish Rue" in United States (2). The flowering period is March to April. The fruits are globose capsules with three chambers containing numerous small dark brown, 3 - $4 \mathrm{~mm}$ long seeds (3). The fruits are used as analgesic and antiseptic in folk medicine (3) and recent pharmaceutical studies proved antibacterial and antiprotozoa properties of $P$. harmala $(4,5)$.

It has been reported that this plant has anti-tumor effects, vasorelaxant effects, anti-HIV, anti-oxidant activity, immune-modulator properties, and hypoglycemic effects $(3,6)$. It has been revealed that some of the pharmacological effects of $P$. harmala may be ascribed to its $\beta$-carboline alkaloids and quinazolin derivatives (3). Alkaloids, flavonoids and anthraquinones are the main phyto-chemical compounds of $P$. harmala.

$\beta$-carboline a like harmaline, harmine, harmalol, harmol and tetrahydroharmine are the main alkaloids present in P. harmala. Herraiz et al. (7) identified that different parts of the plant contains different percentages of the aforementioned alkaloids for example, seeds and roots contain the highest levels of alkaloids however, stems 
and leaves contain lower amounts, and flowers have no alkaloids. Herraiz confirmed that harmine and harmaline accumulate in dry seeds at $4.3 \%$ and $5.6 \%(\mathrm{w} / \mathrm{w})$, respectively, harmalol at $0.6 \%$, and tetrahydroharmine at $0.1 \%(w / w)$ and roots contain harmine and harmol with $2.0 \%$ and $1.4 \%(w / w)$, respectively (7). Harmaline (dihydroß-carboline alkaloid) and harmine (full aromatic ß-carboline alkaloid) are the major alkaloids present in the seeds and the root of P. harmala L. (8) and inhibit monoamine oxidase $\mathrm{A}(\mathrm{MAO})$ as a main in-activator of monoaminergic neurotransmitters which is responsible for a number of neurological disorders (7, 9). Moreover, harmine showed significant tumor inhibition in mice bearing Lewis Lung Cancer, sarcoma180 or HepA tumor (10).

Cancer as one of the main public health problems around the world, is the second leading cause of death following heart disease (11). In economically developed and developing countries, breast cancer in females and lung cancer in males are the most common diagnosed cancers (12). Breast cancer is a complex and heterogeneous disease with both genetic and environmental risk factors. The incidence and mortality rates of this cancer have been rising in many African and Asian countries (12), therefore research on breast cancer is crucial to promote world health, significantly.

Breast cancer cell lines are classified based on histological type, tumor grade, lymph node status and the presence of predictive markers such as estrogen receptor(ER) and human epidermal growth factor receptor 2 (HER2) (13). Breast cancer cell lines, such as MDA-MB-231, SKBR-3, MCF-12A, HBL101, MDA-MD-435, MCF-7, HS598T (14), are frequently used for basic cancer researches. The growth-inhibitory effect of Terminalia chebula fruit was confirmed on several malignant cell lines including MCF7, S115, HOS1, PC-3, and PNT1A cancer cell lines by Saleem et al. (15). Riva et al. (16) studied the anti-proliferative effects of Uncaria tomentosa extracts and its fractions on the growth of breast cancer cell line MCF7. Hostanska et al. studied the anti-proliferative activity of $C$. racemosa extracts (isopropanolic and ethanolic) on estrogen receptor positive MCF7 and estrogen receptor negative MDA-MB231 breast cancer cells by WST-1 assay (17). The positive effects of aqueous extracts of 12 Chinese medicinal herbs, Anemarrhena asphodeloides, Artemisia argyi, Commiphora myrrha, Duchesnea indica, Gleditsia sinensis, Ligustrum lucidum, Rheum palmatum, Rubia cordifolia, Salvia chinensis, Scutellaria barbata, Uncaria rhychophylla and Vaccaria segetalis were evaluated for their antiproliferative activity on eight cancer cell lines by Shoemaker et al. (18). Furthermore, alkaloids such as vinblastine, vincristine and ellipticine have been used as potent anticancer agents (19). Tumor cells were killed by these alkaloids via different mechanisms, such as induction of apoptosis and inhibition of topoisomerase I and II (20-22).

Alkaloids of $P$. harmala, including harmine and harmaline are effective on the human promyelocytic cell line
(HL60 cells) (3). In one study, harmine significantly inhibited the growth of tumor in mice bearing Lewis Lung Cancer, sarcoma180 and HepA tumor (23). To date no study has been carried out to verify the direct human-antitumor activity of $P$. harmala's extracts on breast cancer MDA-MB-231 and Mcf-7 cell line.

\section{Objectives}

In this study, the alkaloids of P. harmala L. seeds containing herbal active principals, harmine and harmaline, were extracted and purified. Two techniques, FT-IR and HPLC, were used to for their precise identification and their effects on two cancer cell lines, MDA-MB-231 and Mcf7 was investigated.

\section{Materials and Methods}

\subsection{Peganum harmala's Alkaloids Extraction}

P. harmal seeds were collected from the mountains of Shahrekord, Chaharmahalo Bakhtiari province and Mashhad, Khorasan Razavi province, Iran. The grinded $P$. harmala seeds were mixed up with $50 \mathrm{~mL}$ glacial acetic acid (30\% (w/w)) and were stirred for 30 minutes at low speed. The mixture was then filtered through a Buchner funnel and Whatman filter paper (No. 5) while it was washed with $20 \mathrm{~mL}$ glacial acetic acid (30\% (w/w)) once more.

The filtrate was washed three times with petroleum ether: ethyl acetate (1:1) to remove the organic impurities by a separator funnel. The aqueous layer was collected and plenty of sodium hydroxide $10 \mathrm{M}$ was added to reach a cloudy appearance. The organic part, which contained alkaloids, mainly hamaline and harmine, was captured in the chloroform phase (100 $\mathrm{mL} x$ three times) in a separator funnel. The solvent was finally removed by the means of rotary evaporation.

\subsection{HPLC Analysis}

HPLC analysis was performed using Cecil 1100 series (Cecil Inst., Ltd., Cambridge, United Kingdom) equipped with a 1100 series pump and UV absorbance detector and a column oven (CTS-30 Younglin, Korea) to detect Cyclomaltooctadecaose (CD18), a cyclic oligosaccharides composed of 18 D-glucose units. The mobile phase consisted of potassium phosphate buffer $(10 \mathrm{mM} \mathrm{pH} \mathrm{7)} \mathrm{and} \mathrm{aceto-}$ nitrile $(50: 50 \mathrm{v} / \mathrm{v})$ with a flow rate of $1.5 \mathrm{~mL}^{\mathrm{min}} \mathrm{m}^{-1}$ at room temperature $\left(25^{\circ} \mathrm{C}\right)$.

Individual stock solutions of harmine and harmaline(Sigma, USA) were prepared at five concentrations of 100 -1000 $\mu \mathrm{g} \cdot \mathrm{mL}^{-1}$ in methanol and used to draw a standard curve.

\subsection{Fourier Transformation Infrared Spectroscopy (FTIR)}

Fourier Transformation Infrared Spectroscopy spectra were recorded on FT-IR spectrophotom-eter (BRUKER, 
Germany) using $\mathrm{KBr}$ discs. The P. harmala extracts $(2 \mu \mathrm{L})$ were coated on the $\mathrm{KBr}$ discs to form thin liquid films for infrared spectrometry analysis. The discs were approximately $5 \mathrm{~mm}$ in diameter and $1 \mathrm{~mm}$ in thickness. The instrument was operated under dry air purge, and the scans were collected at scanning speed of $2 \mathrm{~mm} . \mathrm{s}^{-1}$ with resolution of $4 \mathrm{~cm}^{-1}$ over the region of $4000-400 \mathrm{~cm}^{-1}$.

\subsection{Cell Lines}

Two human breast carcinoma cell lines MDA-MB-231 and Mcf-7 were donated by Dr. Mosa Gardaneh and Eng. Azin Gholami (NIGEB). MDA-MB-231 cell line is negative for ER, PR and HER2 and positive for EGFR, however, Mcf-7 cell line is positive for estrogen receptor (ER) (13). Cancer cell lines were cultured in DMEM medium with $100 \mathrm{U} \cdot \mathrm{mL}^{-1}$ of penicillin, $100 \mu \mathrm{g} . \mathrm{mL}^{-1}$ of streptomycin, and $10 \%$ fetal bovine serum (FBS). The cells were grown at $37^{\circ} \mathrm{C}$ in a humidified $5 \% \mathrm{CO}_{2}$ incubator.

\subsection{Chemicals}

3-(4, 5-Dimethylthiazol-2-yl)-2, 5-diphenyltetrazolium bromide (MTT), harmine (286044-1G), harmaline (51330$1 G$ ) were purchased from Sigma; DMEM, Trypsin, and FBS were purchased from Invitrogen-Life Technologies.

\subsection{Cell Viability by MTT Assay}

The viability of cultured cell lines was determined by the MTT assay, which is based on the reduction of a tetrazolium salt by mitochondrial dehydrogenase of viable cells. Cell lines were seeded ( 8000 cells/well) in a 96 well plate and incubated for 24 hours at $37^{\circ} \mathrm{C}$ in $5 \% \mathrm{CO}_{2}$ incubator and different concentrations of $P$. harmala's alkaloid extract $\left(1,10,20,30,40,50,60,80\right.$ and $\left.100 \mu \mathrm{g} \cdot \mathrm{mL}^{-1}\right)$ were added to each well and the plate was incubated for 24 , 48 , and 72 hours. After incubation, $20 \mu \mathrm{L} \mathrm{MTT} \mathrm{(5} \mathrm{mg.mL}{ }^{-1}$ ) was added to each well to attain a total reaction volume of $200 \mu \mathrm{L}$. The plate was then kept in the incubator for a further 5 hours. Then, the medium was depleted and formazan crystals, which appeared in the last incubation step, were dissolved in $200 \mu \mathrm{L}$ of dimethylsulfoxide. The percentage of viable cells was determined through different absorbances of analytes and controls read by ELISA plate reader at $580 \mathrm{~nm}$.

\subsection{Statistical Analysis}

Statistical analysis was performed using the SPSS (Statistical Package for Social Sciences) software. Analysis of Variance (ANOVA) for repeated measures and Duncan's test were performed to detect changes among the groups. Results represent means \pm SD for at least three replicate determinations for the MTT test. Differences with P values $<0.001$ were considered significant.

\section{Results}

P. harmala seeds were subjected to acidic/basic extraction to achieve their alkaloids content. Seeds and roots of $P$. harmala contain higher alkaloid content, in contrast leaves and stems contain the lowest amounts and flowers have no alkaloids. Harmaline and harmine are the major alkaloids present in the seeds (4.3 and 5.6\% (w/w)) and the root of the P. harmala L., however, harmalol and tetrahydroharmin are present at 0.6 and $0.1 \%$, respectively $(w / w)(4)$. Therefore, when the extract was identified by two methods, FTIR and HPLC, two alkaloids with higher absolute concentrations were recorded, harmaline and harmine (Figures 1 and 2).

To detect the concentration of harmaline and harmine in the extract of P. harmala, the calibration curves were plotted as shown in Figure 3. The inhibitory effect of $P$. harmala extract on two breast cancer cell lines was tested by Methylthiazol Tetrazolium (MTT) assay. The MTT tetrazolium salt colorimetric assay measures cytotoxicity, cell proliferation and cell activation. The level of MTT cleavage by viable cells relatively addresses the increment of cell numbers during the time frame. It has been proved that the cell numbers increases non-linearly. In contrast, cell death follows another rule, a time-linear approach during MTT incubation (24).

Cancer cell lines, MDA-MB-231 and Mcf-7, were exposed to nine concentrations of $P$. harmala extract $(1,10,20,30$, $40,50,60,80$, and $\left.100 \mu \mathrm{g} \cdot \mathrm{mL}^{-1}\right)$ for three days to assay the inhibitory effect of the extracts on cancer cell growth. The half maximal inhibitory concentration $\left(\mathrm{IC}_{50}\right.$ ) was used to measure the suppression of cell growth for cancer lines at different time intervals, 24, 48 and 72 hours. Therefore, it was observed that $30 \mu \mathrm{g} \cdot \mathrm{mL}^{-1}$ is the concentration at which $50 \%$ of cells die at 24 hours in MDA-MB-231 cell line (Figure 4 A). Approximately, the same concentration was recorded when cell line was exposed to harmala's extract for longer times, 48 and 72 hours.

Furthermore, the inhibitory effect of the extract on Mcf7 growth rate was not significant at 24 hours even in the most concentrated treatment $\left(100 \mu \mathrm{g} \cdot \mathrm{mL}^{-1}\right)$, which does not meet the $\mathrm{IC}_{50}$ (Figure $4 \mathrm{~B}$ ). In this cell line, it seemed that the longer exposure time has a meaningful effect on cell death. $40 \mu \mathrm{g} \cdot \mathrm{mL}^{-1}$ and $25 \mu \mathrm{g} \cdot \mathrm{mL}^{-1}$ were calculated for $\mathrm{IC}_{50}$ at 48 and 72 hours, respectively. These findings confirm that both concentration and exposure time have significant effects on Mcf-7 growth inhibition through treatment with P. harmala extract.

Finally, the morphological changes of cells were studied by optical microscopy to distinguish whether apoptosis or necrosis is responsible for cell death (Figure 5). The arrows in Figure 5 indicate the round shape of the cells in both untreated and treated cell lines MDA-MB-231 and Mcf-7 with different concentrations of $P$. harmala extract observed under optical microscopy, 100x. 
A

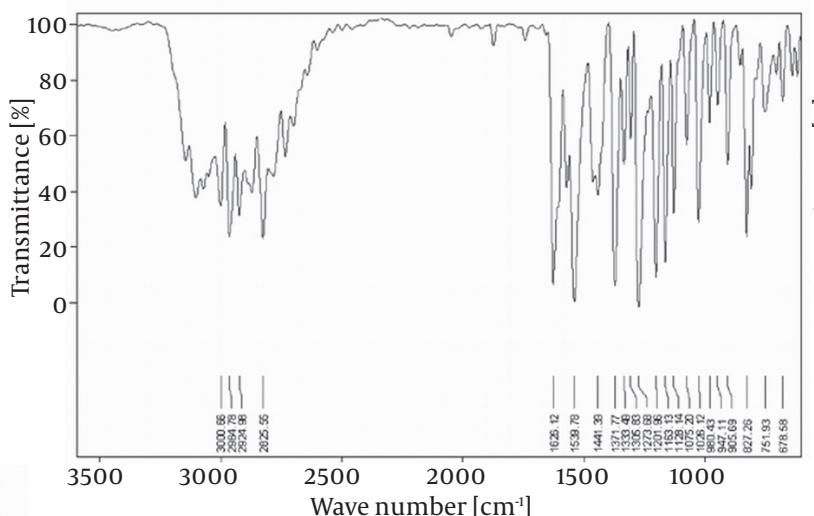

C
B

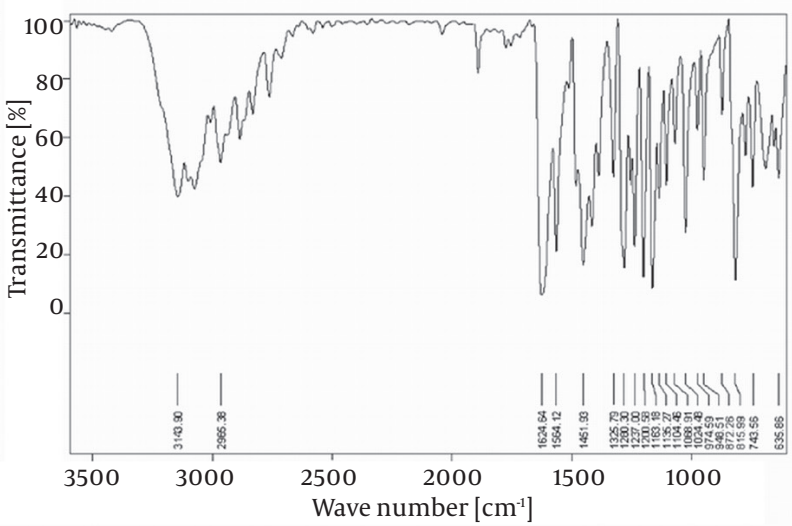

Wave number $\left[\mathrm{cm}^{-1}\right]$

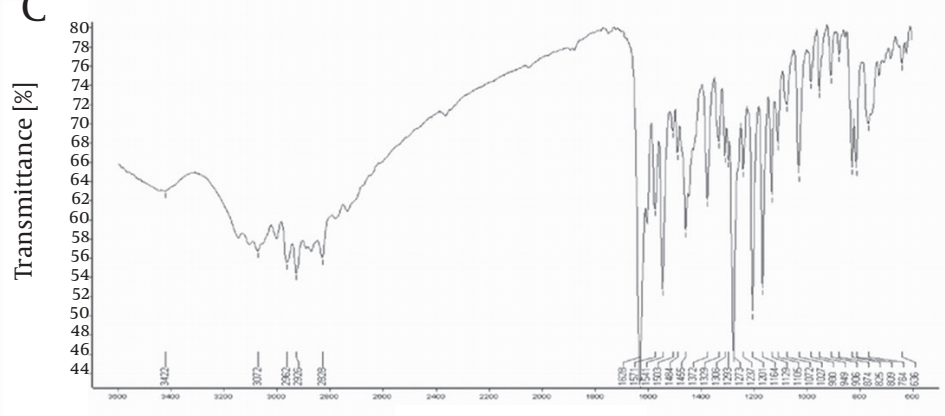

Wave number $\left[\mathrm{cm}^{-1}\right]$

Figure 1. FT-IR Spectra for (A) Harmaline Standard and (B) Harmine Standard and (C) P. harmala Seeds Extract

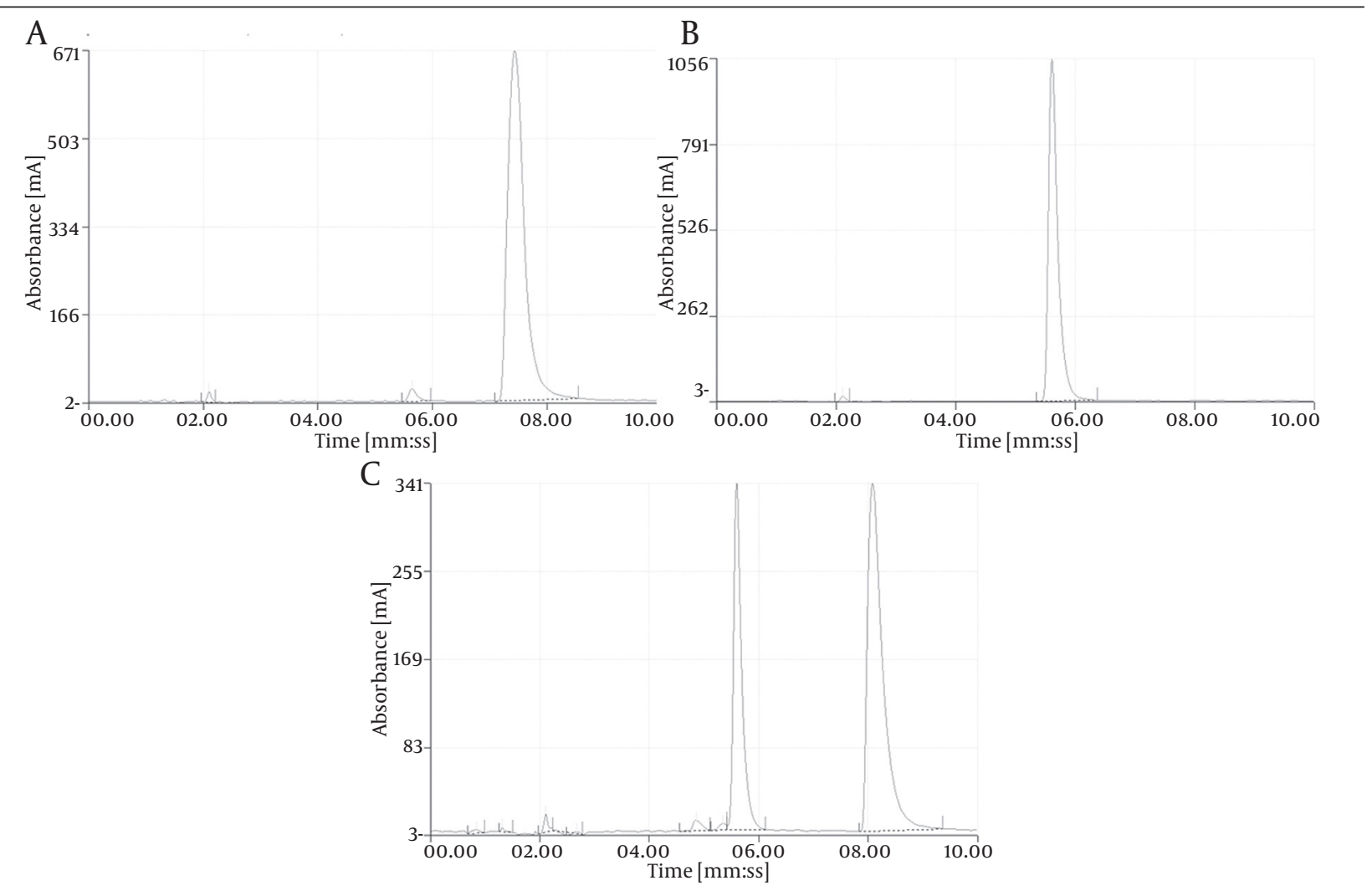

Figure 2. HPLC Chromatogram of (A) Harmaline, (B) Harmine and (C) P. harmala Seeds Extract 
A

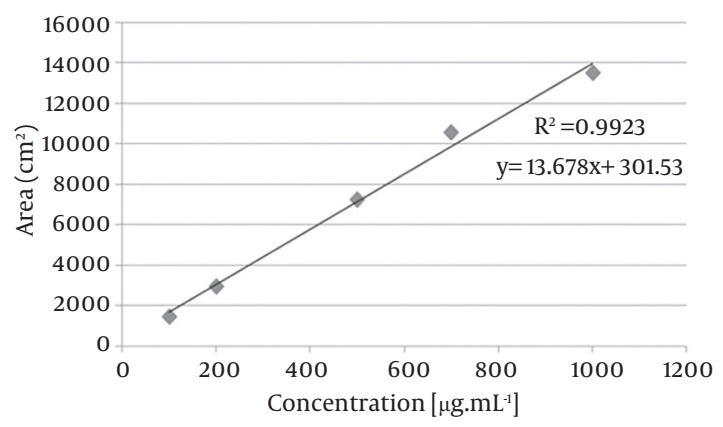

B

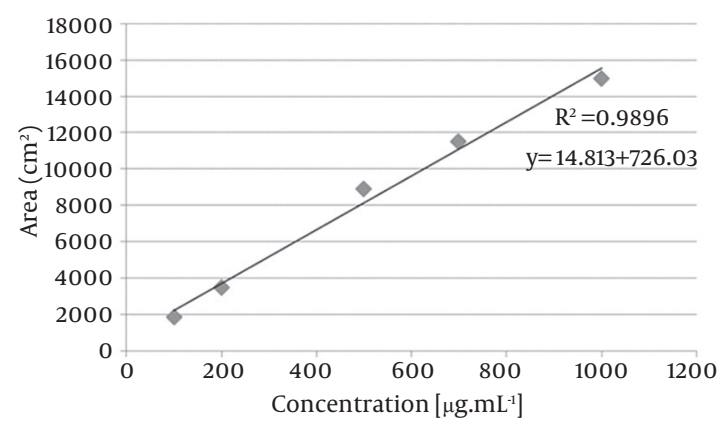

Figure 3. Calibration Curve for (A) Harmaline and (B) Harmine
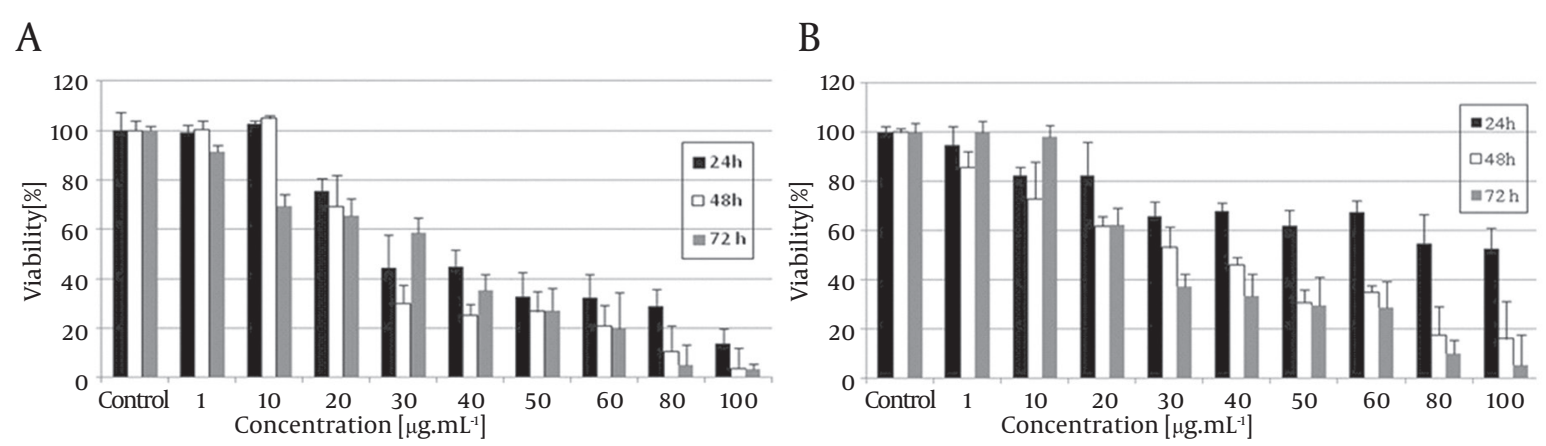

Figure 4. Inhibition of Proliferation of (A) MDA-MB-231 Cancer Cells and (B) Mcf-7 Cancer Cell by the Means of MTT Assay. Each value represents the mean \pm standard deviation of more than three replicates. P values $<0.001$

\section{Discussion}

Herbs, as a natural/green resource with variety of uses including culinary and medicinal, have received much attention during all centuries. However, recently they are studied for their proper effect on some nominated diseases (15-18). Amongst them, P. harmala L., a known folklore medicine containing several alkaloids, has been proved to have anti-cancer effects $(7,20,25)$. In this study, we isolated the alkaloid extraction of $P$. harmala seeds and identified its component by means of two analytical methods, FTIR and HPLC. Although, different alkaloids have been reported to be present in $P$. harmala extract i.e. harmol, harmalol, harmine and harmaline (3), we detected harmine and harmaline as the major components of the extract by FTIR. Our further analyses of cell lines determined that these two major components are the most responsible factors for such results. Figure $1 \mathrm{C} \mathrm{dem}$ onstrates the absorbance of the P. harmala extract compared with harmine and harmaline standards (Figures 1 $A$ and $B$ ) at frequency region of $4000-400 \mathrm{~cm}^{-1}$. The spectrum of $P$. harmala extract was in accordance with harmine and harmaline standards and the absorptions of $P$. harmala extract at different wave lengths, 1072, 1237, 1455, 1624 and 3072 refers to different functional groups (C-H),
$(\mathrm{C}=\mathrm{O}),(\mathrm{C}=\mathrm{N}),\left(\mathrm{OCH}_{3}\right)$ and $(\mathrm{C}-\mathrm{N})$, respectively.

HPLC analysis was used to separate the P. harmala extract components and compared the results with the standard solutions of harmine and harmaline. The chromatograms approved the presence of harmine and harmaline as their retention time at 8.07 and 5.32 minutes, respectively were in accordance with the standard solution (Figures $2 \mathrm{~A}, \mathrm{~B}$, and C). Further analysis of HPLC indicated that harmaline has higher concentration in the $\mathrm{P}$. harmala extract. By means of plotting calibration curves, concentration of $640 \mu \mathrm{g} . \mathrm{mL}-1$ and $189 \mu \mathrm{g} . \mathrm{mL}-1$ for harmaline and harmine, respectively were indicated.

It has been reported that harmine and harmaline have similar pharmaceutically equivalent affects; however, harmine is supposed to be less poisonous, therefore it has more advantageous for use in cancer therapy. In the present research we used total $P$. harmala alkaloids extract to show its effectiveness against growth of two breast cancer cell lines, in vitro. The results of proliferation inhibitory rate analysis (Figures $4 \mathrm{~A}$ and $\mathrm{B}$ ) confirmed that the more concentrated extract, the more potential in cell growth inhibition. However, time of exposure, as another parameter plays an important role in increasing efficiency of cell growth suppression. Although we had to conclude the first parameter, concentration, is a function of 
Figure 5. Cell Morphology of MDA-MB-231; the First Row, (A) Untreated MDA-MB-231 (B) Treated MDA-MB-231 with $25 \mu \mathrm{g} \cdot \mathrm{mL}^{-1}$ of P. harmal Extract for 24 Hours (C) Treated MDA-MB-231 with $100 \mu \mathrm{g} . \mathrm{mL}^{-1}$ of P. harmal Extract for 24 Hours. Cell Morphology of Mcf-7, the Second Row; (D) Untreated Mcf-7 (E) Treated Mcf-7 With $40 \mu \mathrm{g} \cdot \mathrm{mL}^{-1}$ of P. harmal Extract for 48 Hours (F) Treated Mcf-7 With $100 \mu \mathrm{g} \cdot \mathrm{mL}^{-1}$ of P. harmal Extract for 48 Hours (optical microscopy, 100x).

A

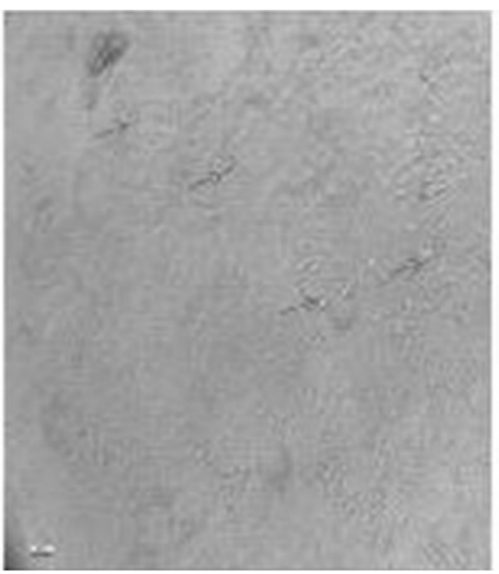

$\mathrm{D}$

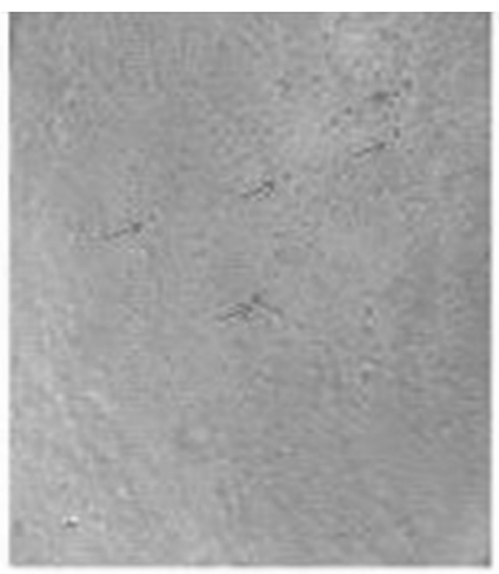

B

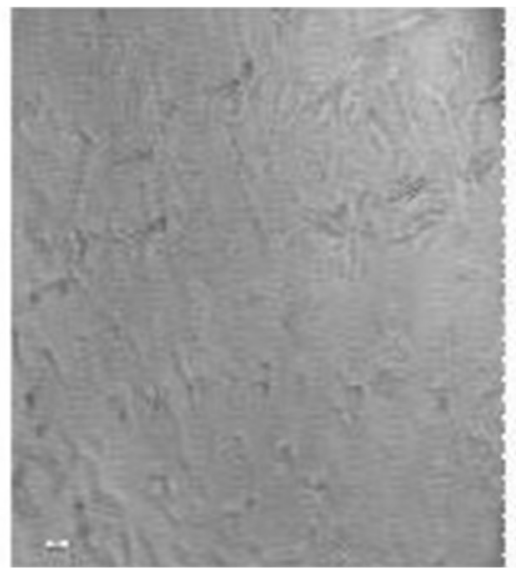

E

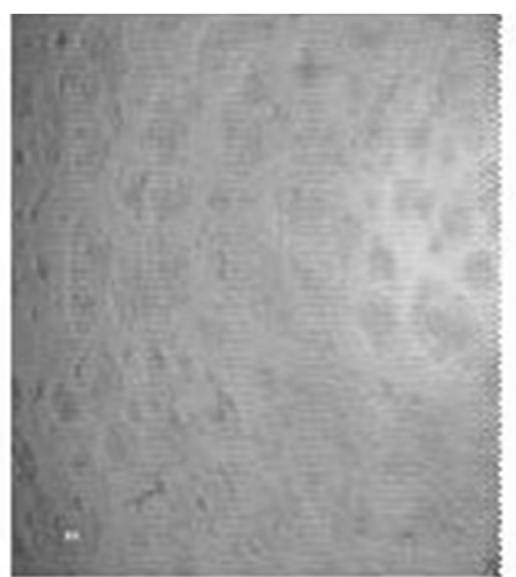

C

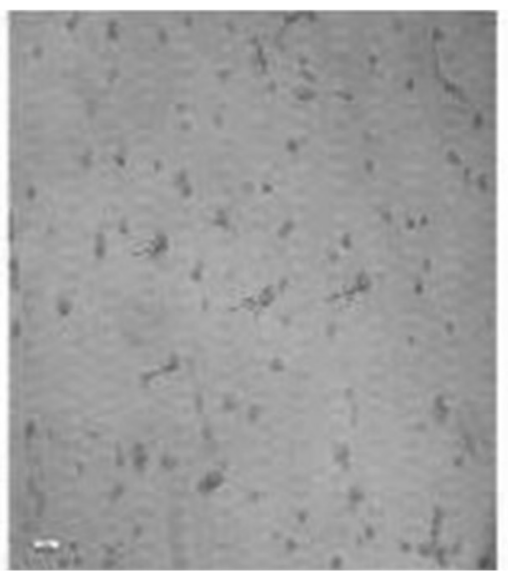

F

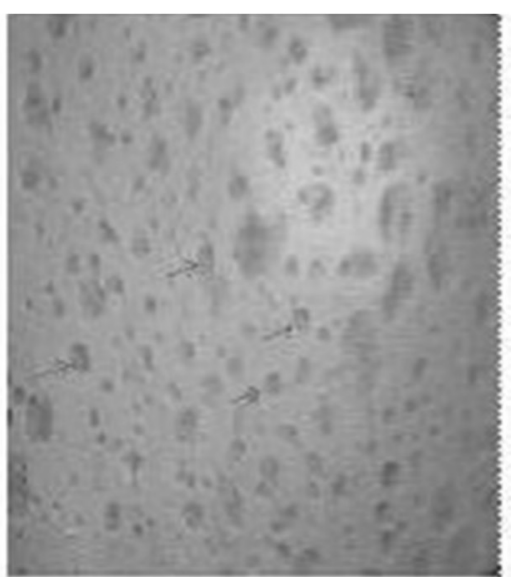

The arrows show the round-shape of cells that confirms apoptosis is responsible for cell death.

other parameter exposure time; since time of exposure did not provide a significant difference when treating MDA-MB-231 with P. harmala extract as the suppression of cell growth for cancer line MDA-MB-231 occurred in lesser time (24 hours) compared with Mcf-7. In contrast, exposure time seems to be crucial in case of Mcf-7 treatment with P. harmala extract; precisely, longer exposure time decreased cell growth rate more vigorously especially at 72 hours. Considering $30-40 \mu \mathrm{g} \cdot \mathrm{mL}^{-1}$ of the extract as $\mathrm{IC}_{50}$, we can conclude that concentration of the extract has greater importance than time of exposure to provide higher cytotoxic effect and cell death. Besides, it is worth noting that MDA-MB-231 cell line naturally has a higher growth rate than Mcf-7 cell line, which may explain higher growth inhibition of MDA-MB-231 cell line by the P. harmala extract. Other studies regarding breast cancer cell line treatment took advantage of hormone replacement therapy. Hostanska et al. found that proliferative activity and cell killing occurs when they exposed MCF-7 and MDA-MB231 against isopropanolic and ethanolic extracts of Cimicifuga racemosa (17). The effective dose for $\mathrm{IC}_{50}$ was calculated to be $80.6 \pm 17.7 \mu \mathrm{g} . \mathrm{mL}^{-1}$ in MCF-7 cells and 58.6 $\pm 12.6 \mu \mathrm{g} \cdot \mathrm{mL}^{-1}$ in MDA-MB231 cells when an ethanolic extract was used. Their results confirmed apoptosis mode of cell death according to microscopic inspection and further analysis.

Furthermore, morphological changes in cell shape investigated under optical microscopy revealed that the lethal effect of $P$. harmala extract on cancer cell line could be a kind of cell death or apoptosis, as no membrane permeabilization was observed and cells kept their membrane intact. However, we believe that other apoptotic 
parameters at the molecular level (caspase activation, cytochrome c release, and oligonucleosomal DNA fragmentation) should be followed to confirm this observation. Similar results by Zhao and Wink, indicate that harmine induces senescence processes in cells which leads to expedited cell death (26). Furthermore, our diagnosis of apoptotic cell death is supported by Hostanska et al. (17).

In conclusion, the results of the current research address the anti-cancer effect of $P$. harmala L. to its alkaloid components mainly hamine and harmaline. The P. harmala extract exposure against two cancer cell lines, MDAMB-231 and Mcf-7, showed cell growth inhibition and in higher concentration/longer time, complete cell death occurred. Cell mortality rate and $\mathrm{IC}_{50}$ data confirmed dose/time-dependent inhibition effect of $P$. harmala on this cancer cell line.

Further studies are suggested to elucidate the mechanism of action of both harmine and harmaline on more human cancer cell lines and eventual use of these herbal active principle compounds in future anti-cancer pharmaceuticals should be considered.

\section{Acknowledgements}

There is no acknowledgment.

\section{Authors' Contribution}

All authors have participated equally in the present study.

\section{Financial Disclosure}

The authors declare that they have no conflict of interest.

\section{Funding/Support}

This work was financially supported by the National Institute of Genetic Engineering and Biotechnology (NIGEB).

\section{References}

1. Harvey AL. Medicines from nature: are natural products still relevant to drug discovery? Trends Pharmacol Sci.1999;20(5):196-8.

2. Mahmoudian M, Jalipour H, Dardashti PS. Toxicity of Peganum harmala: review and a case report. Iran J Pharmacol Ther 2002;1(1):1-4.

3. Asgarpanah J, Ramezanloo F. Chemistry, pharmacology and medicinal properties of Peganum harmala L. Afr J Pharm Pharmacol. 2012;6(22):1573-80

4. Rahimi-Moghaddam P, Ebrahimi SA, Ourmazdi H, Selseleh M, Karjalian M, Haj-Hassani G, et al. In vitro and in vivo activities of Peganum harmala extract against Leishmania major. J Res Med Sci. 2011;16(8):1032-9.

5. Evans AT, Croft SL. Antileishmanial activity of harmaline and other tryptamine derivatives. Phytother Res. 1987;1(1):25-7.
6. Patel K, Gadewar M, Tripathi R, Prasad S, Patel DK. A review on medicinal importance, pharmacological activity and bioanalytical aspects of beta-carboline alkaloid "Harmine". Asian Pac J Trop Biomed. 2012;2(8):660-4.

7. Herraiz T, Gonzalez D, Ancin-Azpilicueta C, Aran VJ, Guillen $\mathrm{H}$. beta-Carboline alkaloids in Peganum harmala and inhibition of human monoamine oxidase (MAO). Food Chem Toxicol. 2010;48(3):839-45.

8. Jimenez J, Riveron-Negrete L, Abdullaev F, Espinosa-Aguirre J, Rodriguez-Arnaiz R. Cytotoxicity of the beta-carboline alkaloids harmine and harmaline in human cell assays in vitro. Exp Toxicol Pathol. 2008;60(4-5):381-9.

9. Kim H, Sablin SO, Ramsay RR. Inhibition of monoamine oxidase A by beta-carboline derivatives. Arch Biochem Biophys. 1997;337(1):137-42.

10. Chen Q, Chao R, Chen H, Hou X, Yan H, Zhou S, et al. Antitumor and neurotoxic effects of novel harmine derivatives and structure-activity relationship analysis. Int J Cancer. 2005;114(5):67582.

11. Siegel R, Naishadham D, Jemal A. Cancer statistics, 2012. CA-CancerJ Clin. 2012;62(1):10-29.

12. Jemal A, Bray F, Center MM, Ferlay J, Ward E, Forman D. Global cancer statistics. CA Cancer J Clin. 2011;61(2):69-90.

13. Holliday DL, Speirs V. Choosing the right cell line for breast cancer research. Breast Cancer Res. 2011;13(4):215.

14. Subik K, Lee JF, Baxter L, Strzepek T, Costello D, Crowley P, et al The Expression Patterns of ER, PR, HER2, CK5/6, EGFR, Ki-67 and AR by Immunohistochemical Analysis in Breast Cancer Cell Lines. Breast Cancer (Auckl). 2010;4:35-41.

15. Saleem A, Husheem M, Harkonen P, Pihlaja K. Inhibition of cancer cell growth by crude extract and the phenolics of Terminalia chebula retz. fruit. J Ethnopharmacol. 2002;81(3):327-36.

16. Riva L, Coradini D, Di Fronzo G, De Feo V, De Tommasi N, De Simone $\mathrm{F}$, et al. The antiproliferative effects of Uncaria tomentosa extracts and fractions on the growth of breast cancer cell line. Anticancer Res. 2001;21(4A):2457-61.

17. Hostanska K, Nisslein T, Freudenstein J, Reichling J, Saller R. Cimicifuga racemosa extract inhibits proliferation of estrogen receptor-positive and negative human breast carcinoma cell lines by induction of apoptosis. Breast Cancer Res Treat. 2004;84(2):151-60.

18. Shoemaker M, Hamilton B, Dairkee SH, Cohen I, Campbell MJ. In vitro anticancer activity of twelve Chinese medicinal herbs. Phytother Res. 2005;19(7):649-51.

19. Cragg GM, Newman DJ. Plants as a source of anti-cancer agents. Ethnopharmacol.2005;100(1-2):72-9.

20. Sobhani AM, Ebrahimi SA, Mahmoudian M. An in vitro evaluation of human DNA topoisomerase I inhibition by Peganum harmala L. seeds extract and its beta-carboline alkaloids. J Pharm Pharm Sci. 2002;5(1):19-23.

21. Funayama Y, Nishio K, Wakabayashi K, Nagao M, Shimoi K, Ohira T, et al. Effects of beta- and gamma-carboline derivatives of DNA topoisomerase activities. Mutat Res.1996;349(2):183-91.

22. Abe A, Yamada H. Harmol induces apoptosis by caspase-8 activation independently of Fas/Fas ligand interaction in human lung carcinoma H596 cells. Anticancer Drugs. 2009;20(5):373-81.

23. Jo M, Kim TH, Seol DW, Esplen JE, Dorko K, Billiar TR, et al. Apoptosis induced in normal human hepatocytes by tumor necrosis factor-related apoptosis-inducing ligand. Nat Med. 2000;6(5):564-7.

24. Gerlier D, Thomasset N. Use of MTT colorimetric assay to measure cell activation. JImmunol Methods. 1986;94(1-2):57-63.

25. Lamchouri F, Settaf A, Cherrah Y, Hassar M, Zemzami M, Atif N, et al. In vitro cell-toxicity of Peganum harmala alkaloids on cancerous cell-lines. Fitoterapia. 2000;71(1):50-4.

26. Zhao L, Wink M. The beta-carboline alkaloid harmine inhibits telomerase activity of MCF-7 cells by down-regulating hTERT mRNA expression accompanied by an accelerated senescent phenotype. PeerJ. 2013;1. 